九州大学学術情報リポジトリ

Kyushu University Institutional Repository

\title{
Anthocyanin Pigments in the Grape Skins of Several Red Vitis vinifera Cultivars bred in Japan
}

Shiraishi, Shin-ichi

University Farm, Faculty of Agriculture, Kyushu University

Watanabe, Yuka

University Farm, Faculty of Agriculture, Kyushu University

https://doi.org/10.5109/23969

出版情報：九州大学大学院農学研究院紀要. 36 (1/2)，pp.63-67，1991-10. Kyushu University バージョン：

権利関係 : 


\title{
Anthocyanin Pigments in the Grape Skins of Several Red Vitis vinifera Cultivars bred in Japan
}

\author{
Shin-ichi Shiraishi and Yuka Watanabe \\ University Farm, Faculty of Agriculture \\ Kyushu University, Kasuyamachi, Fukuoka 811-23, Japan.
}

(Received July 1, 1991)

\begin{abstract}
The anthocyanin pigments of red grapes Vitis vinifera cultivars, 'Kaiji', 'Sekirei ', 'Morgenshön', 'Mario' and 'Unicorn' were examined by thin-layer chromatography and reflection densitometry. Seven spots were separated, and they were identified to pigments by $\mathbf{R f}$ values, molybdate shift and color reactions, except for one unidentified spot. In 'Kaiji', the pigments in decreasing order of concentration, were cyanidin-3-monoglucoside (92\%), delphinidin-3-monoglucoside $(8 \%)$, and traces of peonidin-3-monoglucoside and an unidentified pigment. 'Ruby Okuyama', 'Morgenshön' and 'Sekirei' had constitutions similar 'to 'Kaiji'. Pigments of 'Rizamat', 'Mario' and 'Unicorn', in decreasing order of concentration, were malvidin-, cyaniden-, petunidin-, delphinidin- and peonidin-3-monoglucosides, 'Mario' lacking peonidin-3-monoglucoside. In 'Kaiji', the aglycones were cyanidin (92\%) and delphinidin (8\%). In 'Ruby Okuyama' and 'Morgenshön', the aglycones were in about the same order, and plus petunidin in 'Sekirei'. 'Rizamat' and 'Unicorn' contained five aglycones, in decreasing order of concentration, malvidin, cyanidin, petunidin, delphinidin and peonidin, and peonidin was absent in 'Mario'.
\end{abstract}

\section{INTRODUCTION}

Investigation by Ribereau-Gayon of Vitisvinifera cultivars have indicated that this species is characterized by 3-monoglucosides for five common anthocyanins (Ribérau-Gayon et al., 1955). Rankine et al. and Albach et al. reported that the pigment composition of the majority of red wine cultivars of V.vinifera appeared to conform to a general eight-band pattern when analyzed by paper chromatography. The 3-monoglucosides of peonidin and of cyanidin have been recently identified as major components of certain V.vinifera table grape cultivars (Albach et al., 1963). Anthocyanins isolated from two $\boldsymbol{V}$. vinifera cultivars 'Koshu' and 'Gros Colman' were identified as 3-monoglucosides only (Akuta et al., 1977).

A fresh red skin color is very attractive for table grapes. In Japan, viticulture of vinifera cultivars in open fields is very difficult because of the rainy climate during the growing period. But viticulture under structures enables the production of vinifera cultivars such as 'Flame Tokay' or 'Rizamat' which are fresh red and of high quality. The new V.vinifera cultivars which were recently bred in Japan are well suitable for viticulture under structures.

The present paper is concerned with the identification and qualitative assessment of the anthocyanins of seven red table grapes grown in Japan. 


\section{MATERIALS AND METHODS}

Ripe grapes of 'Kaiji', 'Sekirei', 'Morgenshön' and 'Unicorn' were supplied by N. Uehara, Director of the Uehara Grape Institute in Yamanashi. Ripe grapes of 'Ruby Okuyama', 'Rizamat' and 'Mario' were supplied by T. Simi of the Akitsu Branch Station of the Fruit Tree Research Station.

The methods of sample treatment, isolation of anthocyanins and measurement of the optical densities of the separated spots were the same as in previous report (Shiraishi et al., 1986).

\section{RESULTS AND DISCUSSION}

The parentages and skin colors of grape cultivars examined were shown in Table 1. The skin colors of 'Kaiji', 'Sekirei', 'Morgenshön' and 'Ruby Okuyama' were almost fresh red, but those of 'Rizamat', 'Mario' and 'Unicorn' were dull red or dark red.

Figures 1 and 2 show a tracing from a two-dimensional thinlayer chromatograms of the pigments from 'Kaiji' and 'Rizamat'. The identities of the pigments, as

Table 1. Parentages and skin color of grape cultivars examined.

\begin{tabular}{lll}
\hline \multicolumn{1}{c}{ Cultivar } & \multicolumn{1}{c}{ Parent of cultivar } & \multicolumn{1}{c}{ Skin color } \\
\hline Kaiji & 'Flame Tokay' $\times$ 'Neo Muscat' & Red \\
Sekirei & A bud mutation of 'Kaiji' & Fresh purple-red \\
Morgenshön & 'Katta Kurgan' X 'Kaiji' & Fresh red \\
Ruby Okuyama & A bud mutation of 'Itaria' & Fresh red \\
Rizamat & 'Katta Krugan' $\times$ 'Parkentskij' & Purple-red \\
Mario & 'Rizamat' X 'Neo Muscat' & Reddish purple-black \\
Unicorn & Seedling of V.vinifera cultivar & Dull red \\
\hline
\end{tabular}

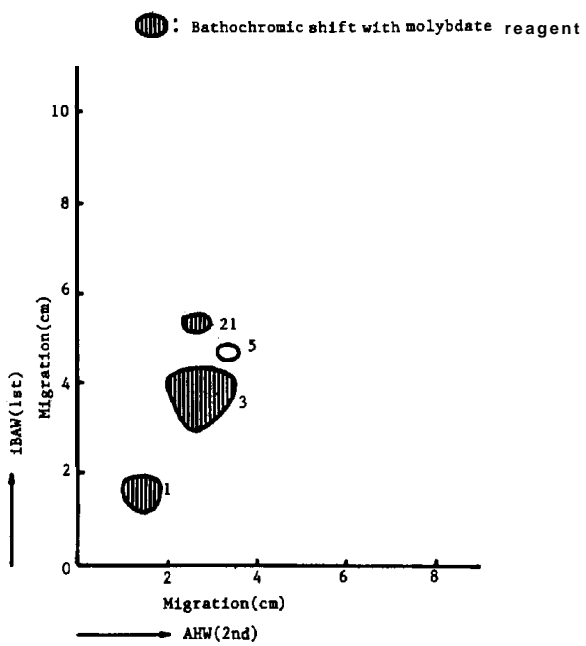

Fig. 1. A two-dimensional thin-layer chromatogram of the anthocyanins in 'Kaiji' 


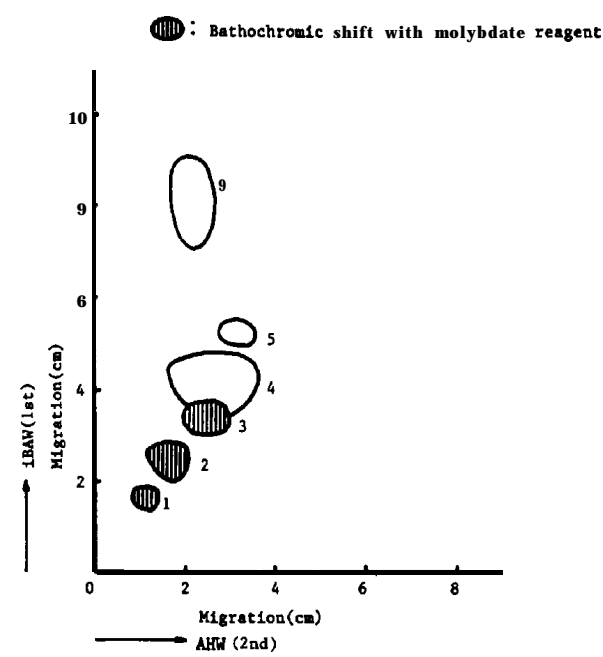

Fig. 2. A two-dimensional thin-layer chromatogram of the anthocyanins in ' $R$ izamat'.

indicated in Tables 2 and 3, are based on the position of the pigments on the twodimentional chromatograms molybdate shift and color reactions, and cochromatography with known pigment samples isolated in prior studies with V.vinifera pigments mixtures using column chromatography method (Ohta et al., 1978). Table 4 lists the percent distribution of the pigments of seven cultivars as determining by chromatogram scanner. Table 5 shows the aglycone constitution of seven cultivars.

In 'Kaiji', cyanidin-3-monoglucoside is by far the major anthocyanin pigment. The cyanidin-derived anthocyanin accounts for $92 \%$ of the total pigments ; the delphinidin derivative is a distant second, $8 \%$; and the peonidin-derived anthocyanin accounts for only a trace. Only an unknown spot at Rf 0.35 on $i$ BAW and 0.18 in $i$ AHW was also recognized and its color changed with molybdate. This spot was also recognized in a trace from 'Ruby Okuyama'. The percent distribution of pigments in 'Ruby Okuyama' and 'Morgenshön' was similar to that of 'Kaiji', the former lacking a trace amount of peonidin-3-monoglucoside, the latter lacking an unknown spot. In 'Sekirei' the major anthocyanin pigment, cyanidin-3-monoglucoside, accounted for 76 $\%$ of the total pigments ; the delphinidin derivative for $22 \%$; and the petunidinderived anthocyanin accounted for only a trace. The ratio of the absorption density of crude extract in $0.1 \% \mathrm{HCl}-\mathrm{MeOH}$ from 'Kaiji' and 'Sekirei' was $10.4: 28.8$ at 535 $\mathrm{nm}$. This result shows the improvement of red color development by a bud mutation in 'Kaiji'.

Major aglycone in 'Rizamat' is malvidin, followed by cyanidin, petunidin, peonidin and delphinidin. The major aglycone of 'Mario' is also malvidin, and in decreasing order of importance are petunidin, cyanidin and delphinidin, this cultivar lacking peonidin. Therefore, seven cultivars examined here are able to be grouped as the 'Kaiji' group, 'Kaiji', 'Sekirei', 'Ruby Okuyama' and 'Morgenshön' and the 'Rizamat' group, 'Rizamat', 'Mario' and 'Unicorn'. The 'Sekirei' group shows fresh red skin 
Table 2. Comparison of $\mathbf{R} \mathbf{f}$ values and colors of individual anthocyanins in examined grapes

\begin{tabular}{ccclll}
\hline \multirow{2}{*}{$\begin{array}{c}\text { Pigment } \\
\text { No. }\end{array}$} & \multicolumn{2}{c}{ Rf value $(\times \mathbf{1 0 0})$ at $25^{\circ} \mathrm{C}$} & \multicolumn{2}{c}{ Color in } & \\
\cline { 2 - 4 } & iBAW & A HW & visible light & UV light & \\
1 & 11 & 8 & Purple & Dull purple & + \\
2 & 17 & 11 & Reddish purple & Dull purple & + \\
3 & 21 & 14 & Red & Dull purple & + \\
4 & 27 & 17 & Red-purple & Dull purple & \\
5 & 32 & 19 & Pink & Dull red-purple & \\
9 & 49 & 15 & Red-purple & Dull purple & \\
21 & 35 & 18 & Red & Dull purple & + \\
\hline
\end{tabular}

Table 3. Identification of the anthocyanins in examined grapes.

\begin{tabular}{|c|c|c|}
\hline Pigment No. & Identification & Abbreviation \\
\hline 1 & Delphinidin-3-monoglucoside & $(\mathrm{Dl}-3 \mathrm{G})$ \\
\hline 2 & Petunidin-3-monoglucoside & $(\mathrm{Pt}-3 \mathrm{G})$ \\
\hline 3 & Cyanidin-3-monoglucoside & $(\mathrm{CY}-3 \mathrm{G})$ \\
\hline 4 & Malvidin-3-monoglucoside & $(\mathrm{Mv}-3 \mathrm{G})$ \\
\hline 5 & Peonidin-3-monoglucoside & $(\mathrm{Pn}-3 \mathrm{G})$ \\
\hline 9 & Malvidin-3-monoglucoside acylated with p-coumarate & $\left(\mathrm{Mv}^{-}-3 \mathrm{G}-\mathrm{Cm}\right)$ \\
\hline 21 & Unidentified $\quad-$ & \\
\hline
\end{tabular}

Table 4. Pacentages of constituent anthocyanins in skin of the examined grapes.

\begin{tabular}{|c|c|c|c|c|c|c|c|c|c|c|}
\hline \multirow[b]{2}{*}{ Pigment } & \multirow[b]{2}{*}{ No. } & \multirow[b]{2}{*}{ Abbreviation } & \multicolumn{8}{|c|}{ Estimated percent of total anthocyanin content } \\
\hline & & & Kaiji & Sekirei & Ruby & Okuyama & Morgenshön & Rizamat & Mario & Unicorn \\
\hline 1 & & $\mathrm{Dl}-3 \mathrm{G}$ & 8 & 22 & & 3 & 2 & 5 & 11 & 17 \\
\hline 2 & & $\mathrm{Pt}-3 \mathrm{G}$ & & 2 & & & & 12 & 14 & 14 \\
\hline 3 & & $\mathrm{Cy}-3 \mathrm{G}$ & 92 & 76 & & 97 & 98 & 13 & 11 & 28 \\
\hline 4 & & $M v-3 G$ & & & & & & 36 & 32 & 26 \\
\hline 5 & & $\mathrm{Pn}-3 \mathrm{G}$ & trace & trace & & & & 8 & & 14 \\
\hline 9 & & $\mathrm{Mv}-3 \mathrm{G}-\mathrm{Cm}$ & - & & & & & 26 & 32 & \\
\hline 21 & & Unknown & trace & - & & trace & & - & & \\
\hline
\end{tabular}

Table 5. Aglycone constitution of the examined grapes.

\begin{tabular}{|c|c|c|c|c|c|c|c|c|}
\hline \multirow{2}{*}{ Aglycone } & \multicolumn{8}{|c|}{ Estimated percent of total aglycone content } \\
\hline & Morgenshön & Ruby & Okuyama & Kaiji & Sekirei & Rizamat & Mario & Unicorn \\
\hline Cyanidin & 98 & & 97 & 92 & 76 & 13 & 11 & 28 \\
\hline Peonidin & & & & trace & trace & 8 & & 14 \\
\hline Delphinidin & 2 & & 3 & 8 & 22 & 5 & 11 & 17 \\
\hline Petunidin & & & & & 2 & 12 & 14 & 14 \\
\hline Malvidin & & & & & & 62 & 64 & 26 \\
\hline Unknown & & & race & trace & & & & \\
\hline
\end{tabular}


color, and the 'Rizamat' group shows dull or dark red, namely, in the former cyanidinderived anthocyanin was the major pigment, and they did not contained methylated anthocyanins, malvidin, petunidin and peonidin, or only a little. In breeding of fresh red cultivars, parents should be made use of 'Kaiji' group which contain high amounts of cyanidin and delphinidin lack methylated anthocyanins, malvidin, petunidin and peonidin.

\section{REFERENCES}

Akuta, A., H. Ohta, Y. Osajima, N. Matsudomi and K. Kobayashi 1977 Studies on anthocyanin pigments in fruits harvested in Japan. V. Anthocyanin pigments in Vitis vinifera varieties, 'Koshu' and 'Gros colman' grapes J. Food Sci. Technol., 24 : 521-523

Albach, R., R. E. Kepner and A. D. Webb 1959 Comparison of anthocyanin pigments of red vinifera grapes. II. Amer. J. Enol. Viticult., $10: 164$

Albach, R. F., R. E. Kepner and A. D. Webb 1963 Peonidin-3-monoglucoside in vinifera grapes. J. Food Sci., $28: 55-58$

Benitley, K. W. 1960 The national pigment. In "The chemistry products. Vol. IV Interscience Publishers, New York, pp. 28

Ohta, H., S. Akuta, S. Shiraishi and Y. Osajima 1978 Anthocyanin Pigments of Three Y-Grape Strains Backcrossed by Vitis vinifera varieties. J. Food Sci. Technol., 25: 421-425

Rankine, S., R. E. Kepner and A. D. Webb 1958 Comparison anthocyanin pigments of vinifera grapes. Amer. J. Enol.Viticult., $9: 105-110$

Ribérea-Gayon, J., P. Sudraud and P. M. Durquety 1955 Relation entre genetique et nature chimique des pigments anthocyaniques de la baie dans le gere Vitis. Revue General de Botanique, 62 :9951005

Shiraishi, S., Y. Watanabe, H. Okubo and S. Uemoto 1986 Anthocyanin Pigmentsof Black-Purple Grapes Related to Variety 'Kyoho' (Vitis vinifera L. $\times$ V. Labrusca L. ).J. Japan. Soc. Hort. Sci., $55: 123-129$ 